\title{
Phytochemical content, antioxidant activities and androgenic properties of four South African medicinal plants
}

\author{
Nelisiwe Prenate Masuku ${ }^{\circledR}$, Jeremiah Oshiomame Unuofin* ${ }^{\mathbb{D}}$, Sogolo Lucky Lebelo ${ }^{\mathbb{D}}$ \\ Department of Life and Consumer Sciences, University of South Africa, Cnr Christiaan de Wet and Pioneer Ave, Private Bag X6, Florida, 1710, South \\ Africa
}

\section{ART I C L E IN F O}

Article Type:

Original Article

Article History:

Received: 24 August 2019

Accepted: 6 November 2019

\section{Keywords:}

Medicinal plants

TM3 Leydig cells

Antioxidants

Cytotoxicity

Testosterone

\begin{abstract}
A B S T R A C T
Introduction: This study aimed to investigate the phytochemical contents, antioxidant activities and androgenic properties of Peltophorum africanum Sond, Trichilia emetica Vahl, Terminalia sambesiaca, and Ximenia caffra.

Methods: The finely powdered leaves of the selected plants were extracted using acetone, aqueous and methanol as solvents. The total phenolics and flavonoids contents were determined from gallic acid and quercetin standard curves. The antioxidant activities of these extracts were evaluated using 1, 1-diphenyl-2-picrylhydrazyl (DPPH) assay. The effects of plant extracts (100-1000 $\mu \mathrm{g} / \mathrm{mL}$ ) on TM3 Leydig cells were assessed using 3-(4,5-dimethylthiazol-2-yl)-2,5diphenyltetrazolium (MTT) assay. Testosterone levels were measured using ELISA kit.

Results: The methanol extracts of T. sambesiaca and $X$. caffra revealed higher total phenolic and flavonoid contents $(102.13 \pm 2.32 \mathrm{mg} / \mathrm{g}$ gallic acid equivalent and $1.05 \pm 0.04 \mathrm{mg} / \mathrm{g}$ quercetin equivalent, respectively) than other plant extracts. The acetone and methanol extracts of $P$. africanum revealed the best $\mathrm{IC}_{50}$ values $(12.50 \pm 0.052 \mu \mathrm{g} / \mathrm{mL})$ against DPPH compared to the other plant extracts and ascorbic acid. The MTT assay results showed that all concentrations of plant extracts maintained cell viability and were not cytotoxic with $\mathrm{IC}_{50}$ values of greater than $20 \mu \mathrm{g} / \mathrm{mL}$. The methanol extract of T. sambesiaca had the higher testosterone production at 500 $\mu \mathrm{g} / \mathrm{mL}(0.399 \mathrm{ng} / \mathrm{mL})$ when compared with the basal control while at the concentration of 500 $\mu \mathrm{g} / \mathrm{mL}$ the acetone extracts of $P$. africanum and T. sambesiaca had significantly high testosterone production of 0.147 and $0.188 \mathrm{ng} / \mathrm{mL}$, respectively when compared with basal control.

Conclusion: The results reveal that these plants possess antioxidants and androgenic properties and suggest the potential use for the treatment of male infertility.
\end{abstract}

Implication for health policy/practice/research/medical education:

The examined medicinal plants and natural products are potent androgenic agents. Their androgenic potentials may improve sexual behaviour and performance, and also boost spermatogenesis and reproduction. The validation of these medicinal plants for their sexual behaviour and fertility may serve as a promising source for the identification of new chemicals for the management and treatment of sexual and erectile dysfunction.

Please cite this paper as: Masuku NP, Unuofin JO, Lebelo SL. Phytochemical content, antioxidant activities and androgenic properties of four South African medicinal plants. J Herbmed Pharmacol. 2020;9(3):245-256. doi: 10.34172/jhp.2020.32.

\section{Introduction}

Medicinal plants have become the main ingredient of medications (1). Many African people, approximately $80 \%$, rely on herbal medicine for alleviation and management of diseases (2). Preference of medicinal herbs over artificial medicine is due to their diversity, accessibility for collection, used in many cultures, self-medication (3), low costs, and minor health effects (4). Medicinal plants are rich in diversity of phytochemicals such as polyphenols with antioxidant properties that can neutralize damaging free radicals and subsequent protecting tissues from oxidative stress (5-7).

Elevated reactive oxygen species (ROS) or free radicals such as hydroxyl radical, hydrogen peroxide and superoxide anion have been found associated with male hypogonadism and infertility (8). Male infertility has become one of the serious medical conditions globally contributing about $50 \%$ of prevalence (9). Testosterone, 
an essential sex hormone synthesised from testicles, plays a critical role in several body's physiological and biological functions. Its deficiency may result in changes that can negatively affect the body's normal function (10). Disturbances of testosterone impair spermatogenesis, male secondary sexual characteristics development, sexual performance and subsequent male infertility (11). Herbal medicines are sources of natural antioxidants used for the treatment and management of male infertility (12). In South Africa, a number of medicinal plants have been used for male reproductive healthcare (13). Some of these plants have not been scientifically evaluated for their potential activity and possible toxicity levels.

Peltophorum africanum Sond belongs to the Fabaceae family. It is well-known as African-wattle, Weeping wattle, Rhodesian black wattle, and African false wattle (English); "dopperkiaat, huilboom, huilbos" (Afrikaans); "Umsehla" (Ndebele); "isiKhaba-mkhombe, umSehle, or umThobo" (Zulu); "mosêtlha" (Tswana) (14). "Mosese" (Venda) (15); and "Mosetlha" (Sepedi) (16). P. africanum is native to Southern Africa, geographically distributed throughout Demographic of Congo, the Northern part of the KwaZulu-Natal province of South Africa and Swaziland $(17,18)$. The plant is also found in Kenya, Madagascar, Australia, Tanzania and the United States (18). The P. africanum bark and root are used for the treatment of tuberculosis, intestinal disorders and male infertility $(13,19)$. Some researchers $(20,21)$ have reported that the root of this plant is used to treat diarrhoea, tonsils, herpes, and as an eye drop to soothe sore eyes. Also, the bark of this multifunctional plant is used to treat erectile dysfunction, sore throat, diarrhoea, dysentery, wounds, and human immune virus/acquired immune deficiency syndrome (HIV/AIDS) (22,23). Moreover, the concoction of both $P$. africanum bark and Elephantorrhiza elephantina bark is also used traditionally for the alleviation of HIV/ AIDS (23).

Trichilia emetica Vahl belongs to the Meliaceae family. This plant is well-known as "umKhuhlu" (Zulu) (24). The tree is distributed in Tropical Africa (25). The bark is used to treat stomach problems, renal problems and to relieve back pain $(26,27)$. The leaves are used by Zulu people to treat dysentery (28). According to Shai et al (29), it is used folklorically for treatment of wounds and Ascaris stomach aches. T. emetica is also used to treat fever, asthma, eye infections, epilepsy, oedema, anthelmintic, and skin diseases. Moreover, the plant is used as aphrodisiac and diuretic (30). A ratio 1:1 of T. emetica bark and chopped roots of Gymnosporia senegalensis is used for the treatment of infertility (31).

Terminalia sambesiaca belongs to the Combretaceae family. Terminalia species are widely distributed in Africa and Asia (32). The stem bark and leaves decoctions are used as medications to treat cancer, stomach ulcers, and appendicitis $(33,34)$. The powdered root bark is used to treat bloody diarrhoea (34). The plant is also used to treat bilharzia, dysmenorrhoea, earache, backache, pneumonia, hookworm, and syphilis (35). Terminalia sericea one of Terminalia species is used in Limpopo Province, South Africa for treatment of male infertility and impotence (36).

Ximenia caffra belongs to the Olacaceae family. The plant is called large sour plum (English); and "mutshili" (Venda) (15). X. caffra origin spans around Kenya, Tanzania, Malawi, Mozambique, Uganda, Zambia and South Africa (14). The leaves or roots of X. caffra is used for constipation, leprosy, stomach pains and tuberculosis (37). X. caffra dried powdered leaves are applied on the skin to heal dermatophilosis, a skin disease caused by bacterium Dermatophilus congolensis (38), and also used for fertility and as a febrifuge (39). The leaves and/or roots are used by the Venda tribe for the treatment of sexually transmitted infections, cough, diarrhoea, and relieve headache (19). The dried powdered root of X. caffra is applied to the wound, and mixed with soup or added in beers to stimulate sexual desire (40). A decoction of leaves is used to treat tonsillitis and sooth inflamed eyes (40). Moreover, a boiled concoction of the $X$. caffra root and the Tabernaemontana elegans root is used to treat diarrhoea and gonorrhoea infections (20).

This study was therefore aimed at investigating the phytochemical contents, antioxidant activities, and androgenic properties of $P$. africanum Sond, T. emetica Vahl, Terminalia sambesiaca, and Ximenia caffra.

\section{Materials and Methods}

Collection and preparation of plant materials

The leaves of $P$. africanum Sond, T. emetica Vahl, Terminalia sambesiaca and X. caffra were collected in the summer season from labeled trees of Lowveld National Botanical Garden of Mpumalanga province, South Africa. The plant materials were rinsed with distilled water and air-dried. The plant materials were then ground into powder using a laboratory electric grinder, and stored in airtight containers until further use. Ethical clearance was approved by the University of South Africa (Unisa), College of the Agriculture and Environmental Sciences Ethics Committee.

Plant material extraction

Acetone, methanol, and distilled water were used as solvents for extractions. Three grams ( $3 \mathrm{~g})$ of powdered plant materials were weighed into $100 \mathrm{~mL}$ bottles and 30 $\mathrm{mL}$ of acetone and methanol were added. The extraction was performed as explained by Masoko et al (40) with slight modifications. The extraction was repeated three times with equal volume of extractants and each extract were merged and filtered through Whatman No 1 filter paper into weighed labeled glass vials and thereafter concentrated to dryness. The aqueous extract was derived 
via concoctions and filtered through Whatman No 1 . The filtrates were concentrated overnight using a freeze-drier (Ultra-Low Temperature Freezer $-86^{\circ} \mathrm{C}$, Vacutec). After concentration to dryness, all the crude extracts of the respective weight were determined and recorded.

\section{Determination of total phenolic content}

The total phenolic contents were determined using the Folin-Ciocalteu method as described by Makkar (41) and modified by Adebayo et al (42). Briefly, $25 \mu \mathrm{L}$ of plant extracts ( $1 \mathrm{mg} / \mathrm{mL}$ stock solution) and gallic acid (0.02-0.1 $\mathrm{mg} / \mathrm{mL}$ ) was added in different test tubes and mixed with $250 \mu \mathrm{L}$ Folin-Ciocalteu reagent for about 5 minutes. The resultant reaction was stopped with $750 \mu \mathrm{L} 20 \%$ anhydrous carbonate. The solution was made up to $5 \mathrm{~mL}$ with 3975 $\mu \mathrm{L}$ distilled water. The solution was kept at the darkroom temperature for about 2 hours. After incubation, $300 \mu \mathrm{L}$ of the solutions were transferred into 96-well plates and absorbance was read at $760 \mathrm{~nm}$ using a microplate reader (Varioska flash, AEC Amersham Pty Ltd). The experiment was performed in triplicate. Gallic acid was used for the standard curve. The phenolic content of each extract was determined from the standard curve: $\mathrm{y}=0.3141 \mathrm{x}+0.0488$; $\mathrm{R}^{2}=0.9996$ and expressed as $\mathrm{mg} / \mathrm{g}$ gallic acid equivalent (GAE). The total phenolic contents of plant extracts calculated using the below formula:

\section{Total phenolic content $=$ GAE $\times \mathrm{V} / \mathrm{m}$}

where, "GAE" is the concentration of gallic acid established from the calibration curve $(\mathrm{mg} / \mathrm{mL})$, "V" is the final volume of extract $(\mathrm{mL})$, and " $\mathrm{m}$ " is the weight of pure plant extract (g) (43).

\section{Determination of total flavonoid content}

The total flavonoid content of the extracts was determined using Yadav and Agarwal (44) method and slightly modified by Adebayo et al (42). Briefly, $100 \mu \mathrm{L}$ of plant extracts $(1 \mathrm{mg} / \mathrm{mL}$ dissolved in solvents) and quercetin $(0.04-2 \mathrm{mg} / \mathrm{mL})$ was mixed with $300 \mu \mathrm{L}$ of methanol, 20 $\mu \mathrm{L}$ of $10 \%$ aluminium chloride and $20 \mu \mathrm{L}$ of $1 \mathrm{M}$ sodium acetate. The solution was made up to $1 \mathrm{~mL}$ with $560 \mu \mathrm{L}$ distilled water. The resultant solutions were allowed to stand at room temperature for about 30 minutes. After 30 minutes of incubation, the absorbance was read at $450 \mathrm{~nm}$ using a microplate reader (Varioska flash, AEC Amersham Pty Ltd). Experiments were performed in triplicate. The flavonoid content of each extract was determined from quercetin standard curve: $\mathrm{y}=3.6518 \mathrm{x}+0.2309 ; \mathrm{R}^{2}=$ 0.9997. The values were expressed as $\mathrm{mg} / \mathrm{g} \mathrm{QE}$. The total flavonoid contents of the plant extracts calculated using the below formula:

$X=C \cdot V / m$

where " $\mathrm{X}$ " is the total flavonoid content, $\mathrm{mg} / \mathrm{g}$ is the plant extract in $\mathrm{QE}$, "C" is the concentration of quercetin established from the calibration curve $(\mathrm{mg} / \mathrm{mL})$, "V" is the final volume of extract $(\mathrm{mL})$ and " $\mathrm{m}$ " is the weight of pure plant extract (g) (45).

Determination of antioxidant activity using DPPH assay The 1, 1-Diphenyl-2-picrylhydrazyl (DPPH) free-radical scavenging activity method as explained by Mensor et al (46), and modified by Hamzah et al (47) was used to measure the antioxidant activity of extracts. Briefly, a solution of $0.051 \mathrm{mM}$ DPPH radical in methanol was prepared. One hundred microlitres of $\mathrm{DPPH}$ radical solution was mixed with $100 \mu \mathrm{L}$ (40 to $500 \mu \mathrm{g} / \mathrm{mL}$ ) each of the various plant extracts/standard drug (vitamin C) in a 96-well microplate were kept at the darkroom temperature for 30 minutes. After incubation, the absorbance was read at $517 \mathrm{~nm}$ using a microplate reader (Varioska flash, AEC Amersham Pty Ltd). DPPH in methanol served as negative control and methanol as blank. All samples were carried out in triplicate. The percentage of inhibition values were calculated using the below formula:

$\%$ Inhibition $=1-\left(\mathrm{Abs}_{\text {sample }} / \mathrm{Abs}\right.$ control $) \times 100$

where, Abs sample, is the absorbance of the sample, Abs control is the absorbance of the negative control. $\mathrm{IC}_{50}$ is the concentration of the sample required for $50 \%$ inhibition of DPPH free radical was determined from the linear regression plots, \% Inhibition against the concentrations of tested plant extracts $(\mathrm{mg} / \mathrm{mL})$.

\section{Cell culture conditions}

The TM3 Leydig cell line derived from mouse testes were obtained from the University of Western Cape cell culture laboratory. The cells were cultured in the cell culture flasks containing Dulbecco's Modified Eagle Medium (DMEM) added $10 \%$ fetal bovine serum (FBS) (complete medium) in the incubator (Thermo Scientific Forma Series II Water Jacket $\mathrm{CO}_{2}$ Incubator) with $5 \% \mathrm{CO}_{2}$ and $37^{\circ} \mathrm{C}$ temperature (48). The cells were allowed to reach $80 \%$ confluence before been split. Cell passaging was done using Mahapatra et al (49) method, with slight modifications.

Cell viability and cytotoxicity assessments

To assess the effects of solvent extracts of P. africanum, T. emetica, T. sambesiaca and X. caffra on TM3 Leydig cells viability was carried out according to method of Mosmann (50) with slight modifications. The acetone and methanol crude extracts were reconstituted in acetone and aqueous in DMSO at a concentration of $100 \mathrm{mg} /$ mL. TM3 Leydig cells $\left(5 \times 10^{3} / 100 \mu \mathrm{L} /\right.$ well $)$ were exposed to $100 \mu \mathrm{L}$ various concentrations of plant extracts $(0.1$ - $1 \mathrm{mg} / \mathrm{mL}$ ) and incubated at $37^{\circ} \mathrm{C}$ with $5 \% \mathrm{CO}_{2}$ for 24 hours. After incubation, the medium was removed and then $25 \mu \mathrm{L}$ MTT ( $5 \mathrm{mg} / \mathrm{mL}$ in PBS) was added to each well. The plates were then incubated for 2 hours at $37^{\circ} \mathrm{C}$. Afterwards, the medium was removed and the converted dye (formazan blue crystals) dissolved in 100 
$\mu \mathrm{L}$ DMSO per well. Afterwards, the plates were kept in the dark place at room temperature for about 30 minutes and the absorbance was read at $570 \mathrm{~nm}$ and $620 \mathrm{~nm}$ for reference using a microplate reader (Varioska flash, AEC Amersham Pty Ltd). Non-treated cells and MTT were used as control and blank, respectively. The samples were tested in triplicate. Percentage cell viability of the sample was calculated using the below equation:

$\%$ cell viability $=\frac{\text { Mean Absorbance of treated cells }}{\text { Mean Absorbance of control }} \times 100$

The percentage inhibitions were then calculated using the following equation:

$\%$ inhibition $=\frac{1-\text { Mean Absorbance of treated cells }}{\text { Mean Absorbance of control }} \times 100$

$\mathrm{IC}_{50}$ results were determined from the linear regression graph, \% inhibition versus test concentrations (51).

Determination of testosterone production

The TM 3 cells were seeded at density of $5 \times 10^{\wedge} 3$ cells/well in 96-well plate, and treated with various concentrations $(0.1,0.25$, and $0.5 \mathrm{mg} / \mathrm{mL})$ of plant extracts in the presence of $1 \mu \mathrm{L}$ anti-human chorionic gonadotropin hormone (Anti-HCG) and were incubated for 24 hours at $37^{\circ} \mathrm{C}$ with $5 \% \mathrm{CO}_{2}$. After 24 hours, the production of testosterone was assessed using the Testosterone ELISA kit according to the manufacturer's instructions (ab108666-Testosterone ELISA Kit).

\section{Statistical analysis}

Statistical analysis was done using Minitab 17 statistical software, Fisher's least significant difference (LSD) and analysis of variance (ANOVA). The significant difference was $P<0.05$. Data were expressed as mean \pm standard deviation.

\section{Results}

Percentage yield crude extracts

The subsequent percentage yield upon the completion of extraction and concentration with various plants $(P$. africanum, T. emetica, T. sambesiaca, and X. caffra) and solvents (acetone, methanol, and water). T. emetica had the highest acetone extract yield (3.7\%), while in the case of methanol extracts, T. sambesiaca had the highest yield $(30.7 \%)$ and the aqueous extract of $X$. caffra had the highest yield (15.7\%) (Table 1).

Total phenolic contents

In this study, the results of the total phenolic content are expressed in $\mathrm{mg}$ of gallic acid equivalent per gram $(\mathrm{mg} / \mathrm{g}$ GAE). Overall, the acetone extracts of all plants had higher total phenolic content. The highest phenolic content in this study was observed in the acetone extract of T. sambesiaca
Table 1. Percentage yield of crude extracts from the selected plant species extracted using acetone, methanol, and water as solvents

\begin{tabular}{lccc}
\hline \multirow{2}{*}{ Samples } & \multicolumn{3}{c}{ Yield (\%) } \\
\cline { 2 - 4 } & Acetone & Aqueous & Methanol \\
\hline P. africanum & $2.3^{\mathrm{a}}$ & $9.0^{\mathrm{a}}$ & $20.3^{\mathrm{a}}$ \\
T. emetica & $3.7^{\mathrm{b}}$ & $4.3^{\mathrm{b}}$ & $8.3^{\mathrm{b}}$ \\
T. sambesiaca & $3.0^{\mathrm{c}}$ & $13.7^{\mathrm{c}}$ & $30.7^{\mathrm{c}}$ \\
X. caffra & $2.3^{\mathrm{a}}$ & $15.7^{\mathrm{d}}$ & $4.0^{\mathrm{d}}$ \\
\hline
\end{tabular}

Values within the same row, with different superscript are significantly different.

$(102.13 \pm 2.32 \mathrm{mg} / \mathrm{g}$ GAE$)$ while the lowest was observed in the methanol extract of T. emetica $(2.22 \pm 0.31 \mathrm{mg} / \mathrm{g}$ GAE). When compared with other methanol extracts, that of $X$. caffra had the highest phenolic content $(29.7 \pm 1.45$ $\mathrm{mg} / \mathrm{g}$ GAE) while the aqueous extract of $T$. sambesiaca $(12.1 \pm 1.22 \mathrm{mg} / \mathrm{g} \mathrm{GAE})$ had the highest content in among other aqueous extracts (Table 2).

Total flavonoid contents

The flavonoid content of these four plants and their respective crude extracts were expressed in $\mathrm{mg}$ of quercetin equivalent per gram (mg/g QE). The acetone extracts of all plants were determined with reference to quercetin and expressed as their equivalents (mg/g QE). The highest flavonoid content in this study was observed in the acetone extract of $X$. caffra $(1.05 \pm 0.04 \mathrm{mg} / \mathrm{g}$ QE) while the lowest was observed in the methanol extract of T. sambesiaca $(0.02 \pm 0.00 \mathrm{mg} / \mathrm{g} \mathrm{QE})$. Summarily, all three extracts of $X$. caffra had the highest flavonoid contents within each of the different solvents of extraction (Table 2).

Antioxidant activities

The DPPH free radical scavenging activity of the various solvent extracts of $P$. africanum, T. emetica, T. sambesiaca, and $X$. caffra when compared with a recognised antioxidant (Ascorbic acid) and their respective concentrations that scavenged $50 \%\left(\mathrm{IC}_{50}\right)$ of the radicals are presented in Table 3, respectively. From the results, all extracts showed lower $\mathrm{IC}_{50}$ values than that of ascorbic acid; hence the extracts were more efficient in scavenging the DPPH radical than ascorbic acid. The acetone and methanol extracts of $P$. africanum scavenged DPPH radical with $\mathrm{IC}_{50}$ of $13.00 \pm 0.010$ and $19.00 \pm 0.010 \mu \mathrm{g} / \mathrm{mL}$, respectively. The aqueous extract of $T$. emetica had the best scavenging capacity $\left(\mathrm{IC}_{50}=348.5 \pm 0.077 \mu \mathrm{g} / \mathrm{mL}\right)$ when compared to other aqueous extracts.

Cell viability

The TM3 Leydig cells were exposed to increasing concentrations of plant extracts $(0.1,0.25,0.5,0.75$, and $1 \mathrm{mg} / \mathrm{mL}$ ) for 24 hours using MTT assay and percentage cell viabilities are illustrated in Figure 1. T. sambesiaca and $X$. caffra showed higher percentages of viable cells at 
Table 2. Total phenolic and flavonoid contents of four selected plant species extracted using acetone, aqueous and methanol

\begin{tabular}{|c|c|c|c|c|c|c|}
\hline \multirow{2}{*}{ Samples } & \multicolumn{3}{|c|}{ Total phenolic contents (mg/g GAE) } & \multicolumn{3}{|c|}{ Total flavonoid contents (mg/g QE) } \\
\hline & Acetone & Aqueous & Methanol & Acetone & Aqueous & Methanol \\
\hline P. africanum & $76.07 \pm 2.99^{a}$ & $7.34 \pm 0.45^{\mathrm{a}}$ & $2.26 \pm 0.29^{a}$ & $0.84 \pm 0.17^{a}$ & $0.007 \pm 0.00^{\mathrm{a}}$ & $0.06 \pm 0.05^{a}$ \\
\hline T. emetica & $7.1 \pm 0.73^{b}$ & $12.1 \pm 1.22^{\mathrm{b}}$ & $2.22 \pm 0.31^{b}$ & $0.44 \pm 0.01^{\mathrm{a}}$ & $0.03 \pm 0.01^{\mathrm{b}}$ & $0.10 \pm 0.02^{b}$ \\
\hline T. sambesiaca & $102.13 \pm 2.32^{c}$ & $12.1 \pm 0.35^{c}$ & $3.25 \pm 0.49^{c}$ & $0.19 \pm 0.01^{b}$ & $0.02 \pm 0.00^{b}$ & $0.02 \pm 0.01^{\mathrm{a}}$ \\
\hline X. caffra & $85.5 \pm 9.27^{d}$ & $6.86 \pm 0.26^{d}$ & $29.7 \pm 1.45^{d}$ & $1.05 \pm 0.04^{c}$ & $0.10 \pm 0.00^{c}$ & $0.12 \pm 0.01^{c}$ \\
\hline
\end{tabular}

Abbreviations: $\mathrm{mg} / \mathrm{g} \mathrm{GAE}$, milligram gallic acid equivalent per gram of extract; $\mathrm{mg} / \mathrm{g} \mathrm{QE}$, milligram quercetin equivalent per gram of extract. Values are expressed as mean \pm standard deviation of 3 replicates. All the superscripts indicate significant difference $(P<0.005)$ between the means. Values within the same column, with different superscript are significantly different.

Table 3. $\mathrm{IC}_{50}$ values of selected plant species on DPPH radical and TM3 Leydig cells using MTT assay

\begin{tabular}{lcccccc}
\hline \multirow{2}{*}{ Samples } & \multicolumn{3}{c}{ DPPH IC $_{50}(\mu \mathrm{g} / \mathrm{mL})$} & \multicolumn{2}{c}{ MTT IC $_{50}(\mu \mathrm{g} / \mathrm{mL})$} \\
\cline { 2 - 6 } & Acetone & Aqueous & Methanol & Acetone & Aqueous & Methanol \\
\hline P. africanum & $12.50 \pm 0.052^{\mathrm{a}}$ & $830.0 \pm 0.513^{\mathrm{a}}$ & $19.00 \pm 0.010^{\mathrm{a}}$ & $850.0 \pm 0.257^{\mathrm{a}}$ & $946.0 \pm 0.043^{\mathrm{a}}$ & $68.00 \pm 0.001^{\mathrm{a}}$ \\
T. emetica & $109.0 \pm 0.055^{\mathrm{a}}$ & $348.5 \pm 0.077^{\mathrm{b}}$ & $24.00 \pm 0.003^{\mathrm{a}}$ & $65.00 \pm 0.023^{\mathrm{b}}$ & $214.0 \pm 0.002^{\mathrm{b}}$ & $222.0 \pm 0.048^{\mathrm{b}}$ \\
T. sambesiaca & $685.5 \pm 0.108^{\mathrm{a}}$ & $536.5 \pm 0.077^{\mathrm{ab}}$ & $500.5 \pm 0.076^{\mathrm{b}}$ & $451.0 \pm 0.018^{\mathrm{c}}$ & $501.0 \pm 0.008^{\mathrm{c}}$ & $905.0 \pm 0.025^{\mathrm{c}}$ \\
X. caffra & $521.5 \pm 0.209^{\mathrm{a}}$ & $472.0 \pm 0.102^{\mathrm{ab}}$ & $174.0 \pm 0.014^{\mathrm{c}}$ & $246.0 \pm 0.197^{\mathrm{d}}$ & $749.0 \pm 0.138^{\mathrm{d}}$ & $244.0 \pm 0.004^{\mathrm{d}}$ \\
\hline
\end{tabular}

Ascorbic acid $1473.3 \pm 1.335$

The $I C_{50}$ value represents the concentration of the extract required for $50 \%$ inhibition of cells.

Values are expressed as mean \pm standard deviation of 3 replicates. All the superscripts indicate significant difference $(P<0.005)$ between the means. Values within the same column, with different superscript are significantly different.

$1 \mathrm{mg} / \mathrm{mL}(78 \%$, and $106 \%$, respectively) (Figure $1 \mathrm{~A}) . P$. africanum and T. emetica showed higher percentages of viable cells at $0.75 \mathrm{mg} / \mathrm{mL}$ and $0.5 \mathrm{mg} / \mathrm{mL}$ (72\% and $83 \%$, respectively) (Figure 1A). P. africanum and T. sambesiaca showed significantly high percentages of viable cells at $0.25 \mathrm{mg} / \mathrm{mL}$ (94\% and 116\%, respectively). T. emetica and $X$. caffra showed higher percentages of viable cells at $0.1 \mathrm{mg} / \mathrm{mL}$ (91\% and 103\%, respectively) (Figure 1B). $P$. africanum and T. emetica showed significantly high percentage of viable cells at $0.75 \mathrm{mg} / \mathrm{mL}$ and $1 \mathrm{mg} / \mathrm{mL}$ (110\% and $109 \%$, respectively). T. sambesiaca and X. caffra both showed high percentages of viable cells at $0.1 \mathrm{mg} / \mathrm{mL}$ (115\% and $87 \%$, respectively) (Figure 1C).

\section{Cytotoxicity}

Table 3 shows the results of the cytotoxic effects of the extracts. The cytotoxic effects were expressed as $\mathrm{IC}_{50}$ values for the percentage inhibition graph (data not shown). The higher $\mathrm{IC}_{50}$ values indicate the lower cytotoxicity. According to the findings, acetone and aqueous extracts of $P$. africanum $\mathrm{IC}_{50}$ values $(850.0 \pm 0.257$ and $946.0 \pm$ $0.043 \mu \mathrm{g} / \mathrm{mL}$ ) respectively, the methanol extract of $T$. sambesiaca $\mathrm{IC}_{50}$ value $(905.0 \pm 0.025 \mu \mathrm{g} / \mathrm{mL})$ while the aqueous extract of $X$. caffra $\mathrm{IC}_{50}$ value $(749.0 \pm 0.138 \mu \mathrm{g} /$ $\mathrm{mL}$ ). The above extracts showed the lowest cytotoxicity against TM3 Leydig cells (Table 3).

\section{Testosterone production}

Table 4 shows the results of testosterone production in TM3 Leydig cells exposed to selected concentrations of $P$. africanum, T. emetica, T. sambesiaca, and X. caffra solvent extracts treated with anti-human chorionic gonadotropin hormone (anti-hCG). As soon as the plant extracts were introduced, there was an increase in testosterone production levels in non-stimulated TM3 Leydig cells in comparison to control. It is noteworthy to state that at 500 $\mu \mathrm{g} / \mathrm{mL}$, the methanol extract of T. emetica $(0.399 \mathrm{ng} / \mathrm{mL})$ had the highest testosterone production on TM3 Leydig cells in comparison to control. Also, three extracts (acetone, methanol and aqueous extracts) of $P$. africanum at $500 \mu \mathrm{g} /$ $\mathrm{mL}$ showed increased testosterone production on TM3 Leydig cells. In addition, $250 \mu \mathrm{g} / \mathrm{mL}$ of acetone extract, 100 and $250 \mu \mathrm{g} / \mathrm{mL}$ of the methanol extract, and $100 \mu \mathrm{g} / \mathrm{mL}$ of the aqueous extract of $P$. africanum caused significant $(P<0.05)$ decrease in testosterone levels when compared with the control. At the different concentrations tested, $T$. emetica solvent extract had better testosterone production potential when compared to control. Meanwhile, in $T$. sambesiaca only at $100 \mu \mathrm{g} / \mathrm{mL}$ of the acetone extract had significantly $(P<0.05)$ lower levels in testosterone when compared with control. Finally, the acetone and methanol extracts of $X$. caffra caused significant $(P<0.05)$ decrease in testosterone levels when compared with control while the aqueous extract at $250 \mu \mathrm{g} / \mathrm{mL}$ showed an increase in the testosterone production on the TM3 Leydig cells in comparison with control (Table 4).

\section{Discussion}

Phytochemical screening of medicinal plants is mainly depended on the solvent selected for extraction $(6,40)$. The structures of compounds determine their solubility in the solvent polarity (52). Therefore, it is very important 


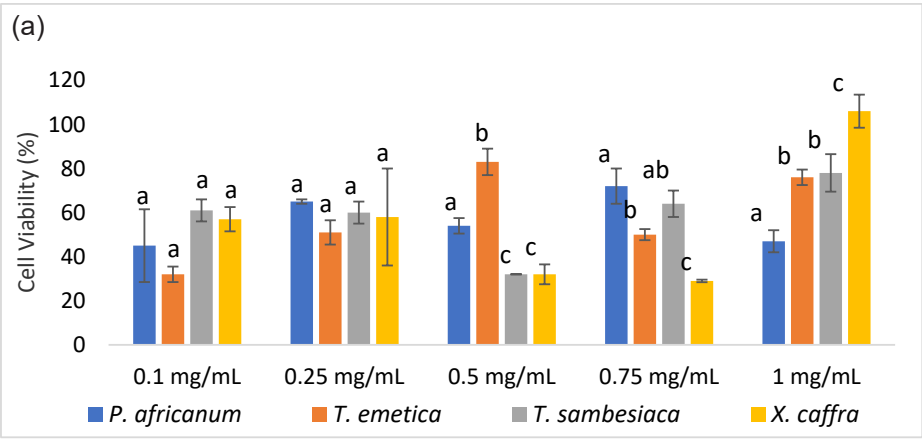

(b)

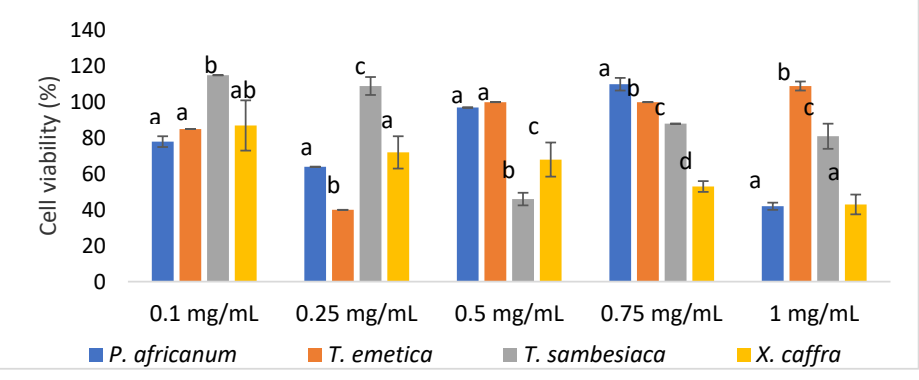

(c)

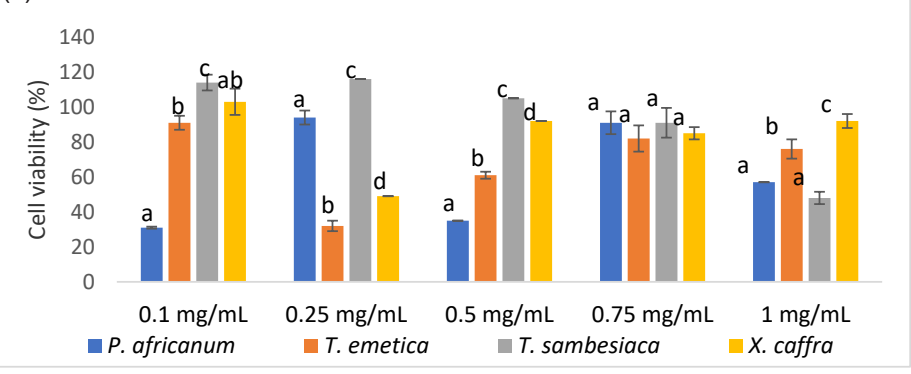

Figure 1: Percentage cell viability of TM3 Leydig cells exposed to different concentrations $(0.1,0.25,0.5,0.75$ and $1 \mathrm{mg} / \mathrm{mL})$ of 4 selected plant species for $24 \mathrm{~h}$ using MTT assay. (A) Acetone extracts (B) methanol extracts and (C) aqueous extracts. The values in the bar chart are expressed as mean (cell viability $) \pm \mathrm{SD}(\mathrm{n}=3)$. Mean separation was done by LSD $(P<0.05)$. Sets of bars (the same concentration) with different alphabets are significantly different; $P<0.05$.

to isolate non-polar compounds with nonpolar solvents and polar compounds with polar solvents (53). In the current study, it was observed that methanol was the best extractant in comparison to other solvents (Table 1). Our results are in support with the study of Masoko et al (54) reported the highest quantity of crude extract obtained with methanol as solvent of extraction.

Phenolic compounds are major secondary metabolites found abundantly in medicinal plants (55). They possess the antioxidant properties that protect the damaging effect of free radical scavenging activity (56). They are believed to account for the antioxidant activity of most plant species (57). From our findings, the acetone extracts of $P$. africanum, T. sambesiaca, and X. caffra had significantly higher total phenolic and flavonoid contents in comparison with other solvent extracts evaluated in this study (Table 2). The study by Mulaudzi et al (38) revealed the total phenolic content of $50 \%$ methanol leaf extract of $X$. caffra $11.87 \pm 0.08 \mathrm{mg} / \mathrm{g}$ GAE lower than that of our study where $100 \%$ methanol was used. The presence of higher phenolic content may be responsible for the antioxidant activity of selected plant species. The results showed that acetone could be regarded as a good solvent for isolating phenolic compounds. Our findings are in line with Unuofin et al (6). They reported that the acetone extract of $V$. mespilifolia had the ability to extract more phytochemical content than other extractants used. Also, the findings are in line with Masuku and Lebelo (58) which obtained higher total phenolic and flavonoid contents from acetone extract of Kigelia africana leaves.

Over the years, the impacts of extractants on medicinal plants and natural products/remedies have been reviewed. In order to have a greater yield of desired phytochemicals during extraction procedures, the polarity index of the solvent of extraction must be carefully addressed $(6,59,60)$. In recent times, researchers have correlated the abundance of polyphenolic contents and other bioactive compounds in natural products to their radical scavenging potential 
Table 4. Testosterone production in TM3 Leydig cells exposed to selected varying concentrations of the extracts for $24 \mathrm{~h}$ in the presence of anti- human chorionic gonadotropin hormone (hCG)

\begin{tabular}{|c|c|c|c|c|c|c|c|c|c|c|}
\hline \multirow{3}{*}{ Samples } & \multicolumn{10}{|c|}{ Testosterone (ng/mL) } \\
\hline & \multicolumn{3}{|c|}{ Acetone } & \multicolumn{3}{|c|}{ Methanol } & \multicolumn{3}{|c|}{ Water } & \multirow{2}{*}{$\begin{array}{c}\text { Negative } \\
\text { control }\end{array}$} \\
\hline & $100 \mu \mathrm{g} / \mathrm{mL}$ & $250 \mu \mathrm{g} / \mathrm{mL}$ & $500 \mu \mathrm{g} / \mathrm{mL}$ & $100 \mu \mathrm{g} / \mathrm{mL}$ & $250 \mu \mathrm{g} / \mathrm{mL}$ & $500 \mu \mathrm{g} / \mathrm{mL}$ & $100 \mu \mathrm{g} / \mathrm{mL}$ & $250 \mu \mathrm{g} / \mathrm{mL}$ & $500 \mu \mathrm{g} / \mathrm{mL}$ & \\
\hline P. africanum & $0.063 \pm 0.003 *$ & $0.011 \pm 0.001$ & $0.147 \pm 0.007^{*}$ & $0.002 \pm 0.000$ & $0.008 \pm 0.000$ & $0.084 \pm 0.004 *$ & $0.017 \pm 0.001$ & $0.053 \pm 0.003 *$ & $0.064 \pm 0.003 *$ & \\
\hline T. emetica & - & $0.065 \pm 0.003 *$ & $0.042 \pm 0.031$ & $0.050 \pm 0.002 *$ & - & $0.042 \pm 0.002$ & $0.092 \pm 0.004$ & $0.054 \pm 0.003 *$ & $0.046 \pm 0.002 *$ & \\
\hline T. sambesiaca & $0.008 \pm 0.000$ & - & $0.118 \pm 0.006 *$ & - & $0.042 \pm 0.002$ & $0.399 \pm 0.019 *$ & - & $0.105 \pm 0.005^{*}$ & $0.067 \pm 0.003^{*}$ & \\
\hline X. caffra & - & $0.008 \pm 0.000$ & $0.015 \pm 0.001$ & $0.004 \pm 0.000$ & $0.023 \pm 0.001$ & $0.019 \pm 0.001$ & $0.031 \pm 0.001$ & $0.073 \pm 0.003 *$ & $0.038 \pm 0.002$ & \\
\hline $\begin{array}{l}\text { Negative } \\
\text { control }\end{array}$ & & & & & & & & & & $0.038 \pm 0.002$ \\
\hline
\end{tabular}

Values represent mean \pm SD of three determinations.

$* P<0.05$ when anti-hCG-stimulated treated groups were compared with the negative control. (-) indicates that the concentration was not measured.

(61-64). Phytochemicals in the form of phenols and flavonoids possess different capacities such as electron donation, metal chelating and oxygen quenchers potential $(65,66)$. All these abilities aid in combating/reducing the accumulation of free radicals in living organisms.

Numerous assays have been developed to measure the free radical scavenging activity of antioxidants in food, beverages, and plant extracts. Good examples are the 2,2-diphenyl-1-picrylhydrazyl (DPPH) and 2,2'-azinobis-3-ethyl-benzothiazoline-sulfonic acid (ABTS) radical scavenging assays. These two assays are regarded as the most popular spectrophotometric methods used to evaluate the antioxidant activity of samples (67). These assays are simple to use and rapid to assess the antioxidant activity, but they are very sensitive to light (68). In the current study, DPPH radical assay was used to determine the radical scavenging potentials of $P$. africanum, $T$. emetica, T. sambesiaca, and X. caffra extracts. The DPPH radical is a purple colour compound, upon reaction with antioxidant it decolorizes to light yellow diphenyl2- picryl hydrazine by accepting hydrogen atom from antioxidants (69). The degree of colour change at the end of the reaction is proportional to the free radical scavenging activity of antioxidants (70).

Our findings revealed that all plant extracts effectively reduced the DPPH radical than ascorbic acid. The presence of lower $\mathrm{IC}_{50}$ value indicates stronger antioxidant activity against damaging free radicals (71). The acetone and methanol extract of $P$. africanum had the best scavenging potential against $\mathrm{DPPH}$ radical with $\mathrm{IC}_{50}$ of $12.5 \pm 0.052 \mu \mathrm{g} / \mathrm{mL}$ and $19.00 \pm 0.010 \mu \mathrm{g} / \mathrm{mL}$ respectively when compared with other plant extracts and standard (ascorbic acid). The methanol extracts of T. emetica, $T$. sambesiaca, and $X$. caffra had the best scavenging power with $\mathrm{IC}_{50} 24.00 \pm 0.003 \mu \mathrm{g} / \mathrm{mL}, 500.5 \pm 0.076 \mu \mathrm{g} / \mathrm{mL}$ and $174.0 \pm 0.014 \mu \mathrm{g} / \mathrm{mL}$, respectively when compared to other solvent extracts of these plants. The aqueous extract of T. emetica had the best scavenging strength $\left(\mathrm{IC}_{50} 348.5\right.$ $\pm 0.077 \mu \mathrm{g} / \mathrm{mL}$ ) when compared with the other aqueous extract tested against DPPH radical (Table 3). The study by Bizimenyera et al (72) measured the DPPH radical scavenging activity of acetone extract of $P$. africanum (leaf, root, and bark) with $\mathrm{IC}_{50}$ values of $6.54 \pm 0.49,3.82 \pm 0.58$ and $4.37 \pm 0.41 \mu \mathrm{g} / \mathrm{mL}$. Adebayo et al (42) determined the antioxidant activity of $70 \%$ acetone leaves extract of $P$. africanum using DPPH assay, in which the results showed $\mathrm{IC}_{50}$ of $7.71 \pm 0.36 \mu \mathrm{g} / \mathrm{mL}$. The review article by Komane et al (73) reported the DPPH radical reducing activity of methanol and aqueous leaf extracts of T. emetica showed $\mathrm{IC}_{50}$ values of 17.9 and $43.9 \mu \mathrm{g} / \mathrm{mL}$. Tshikalange et al (74) demonstrated the DPPH radical inhibition activity of ethanol extracts of $X$. caffra bulbs, roots, and seeds, in which the results showed $\mathrm{IC}_{50}$ values of $11.77,10.41$ and $9.21 \mu \mathrm{g} / \mathrm{mL}$. On the contrary to our study, the antioxidant activity of acetone, hexane, dichloromethane, methanol, and ethyl acetate extracts of T. sambesiaca leaves was observed on the thin layer chromatography using DPPH methanol solution spray as an indicator. Acetone, ethyl acetone and methanol exhibited inhibition activity on the TLC plates $(75,76)$. Inconsistent with the findings reported by Bizimenyera et al (72) and Adebayo et al (42), the $\mathrm{IC}_{50}$ values of $P$. africanum and T. emetica leaves extracts showed weak inhibition activities against DPPH radical in comparison with other studies. It could be as a result of variation in season of harvest of plant materials and geographical location (77). The $\mathrm{IC}_{50}$ values of ethanolic extracts of $X$. caffra bulbs, roots, and seeds were lower in comparison with acetone, aqueous, and methanol leaves extracts of X. caffra of our study. In terms of T. sambesiaca, to our knowledge, this is the first study to determine the $\mathrm{IC}_{50}$ value of these plant crude extracts. Several variables may influence the levels of bioactive compounds of the plant and antioxidant capacities such as type or polarity of solvents used, extraction technique, duration of extraction, temperature, the origin of the plant, and harvest seasons $(77,78)$. These reasons may explain the contrasting result gotten from different studies.

Apart from phenolic compounds, it was reported that 
the antioxidant activity could be due to other bioactive compounds (alkaloids and saponin) in the extracts (62). Catechin, gallotannin, berginin, proanthocyanidins, coumarins, benzenoids, condensed flavonoids, lactone, amino acid, and terpenoids are detected from $P$. africanum extract (79-81). Kurubasch aldehyde, kurubasch aldehyde benzoate, trichilin A, dregeana 4 , trichilia substance ( $\mathrm{Tr}$ A, Tr-B, and Tr-C), nymania 1, seco-A protolimonoid, sendanin, and rohituka-3, rohituka-4, and rotihuka- 7 have been isolated from $T$. emetica extract $(73,82)$. The presence of the saponin-like compound has been identified on the TLC plate loaded T. sambesiaca crude extract (32) and beta-sitosterol was isolated from $T$. sambesiaca extract by nuclear magnetic resonance (74). In the study of Zhen et al (83), the phytochemical analysis of $X$. caffra leaf extract using liquid chromatography-mass spectrometry (LC-MS) showed the presence of gallic acid, quercetin, kaempferol, and catechin. In addition, the antioxidant capacity of the plants is most times dependent on the chemical structure of the antioxidant and its interaction with other plant constituents $(84,85)$. Therefore, other bioactive compounds that contribute to the therapeutic effect of medicinal plants need to be considered as their mechanisms of action (59).

3-(4, 5-Dimethylthiazol-2-yl]-2, 5-diphenyltetrazolium bromide (MTT) assay is a popular method used to evaluate the effects of toxic substances on the cell viability and cytotoxicity (86). MTT is a yellow tetrazolium salt soluble in water. When cells are exposed to MTT solution, it changes to purple formazan product by viable cells. The MTT formazan product cannot pass through the cell membrane of dead cells. It is produced when the tetrazolium ring split by mitochondria succinate dehydrogenase enzyme of viable cells. For this reason, when the number of viable cells increases, the intensity of the purple colour of MTT formazan increases (51). The TM3 Leydig cells were used in this present study. They were gotten from mouse testis. The cells are sited within the interstitial space where almost $95 \%$ of androgenesis takes place (8789). The study revealed the indices of cytotoxicity via cell mortality using MTT assay in TM3 Leydig cell line after 24 $\mathrm{h}$ incubation period with the different plant extracts. The results from this study revealed that the concentrations of $100-1000 \mu \mathrm{g} / \mathrm{mL}$ of all different solvent plant extracts did not alter the viability of TM3 Leydig cells upon 24 $\mathrm{h}$ treatment. This was also observed by Opuwari and Monsees (88), who reported the concentration-dependent increased percentage cell viability from $250-1000 \mu \mathrm{g} / \mathrm{mL}$ when TM3 Leydig cells were exposed to Camellia sinensis (unfermented and fermented rooibos) and Aspalathus linearis (green tea and black) but reduced at $5000 \mu \mathrm{g} / \mathrm{mL}$. The inhibition of growth of the normal TM3 Leydig cells by different plant extracts ranged between 65 and $946 \mu \mathrm{g} /$ $\mathrm{mL}$. Different researchers have stated that the National Cancer Institute residing in the United State of America put up a threshold of an $\mathrm{IC}_{50}$ less than $20 \mu \mathrm{g} / \mathrm{mL}$ for crude extracts as cytotoxic level on cell lines with an exposure period of 24 hours $(61,90)$. From the above assertion, we can say that our different extracts were not cytotoxic.

Human chorionic gonadotropin (hCG) purified from the urine of pregnant women is one the hormones used in therapy to stimulate or improve spermatogenesis in men with low or no spermatogenesis caused by a deficiency in gonadotropin, luteinizing hormone (LH) and follicle-stimulating hormone (FSH). Human chorionic gonadotropin has a similar effect as $\mathrm{LH}$, hence it has been used to replace LH. It stimulates testosterone production by Leydig cells (91). The TM3 Leydig cells and anti-hCG were used in this study to examine the effects of varying concentrations of $P$. africanum, T. emetica, $T$. sambesiaca and $X$. caffra in testosterone production. We determined the testosterone levels via ELISA kit by using cell supernatant obtained after treatment with varying concentrations of $P$. africanum, T. emetica, T. sambesiaca and $X$. caffra with anti-hCG for 24 hours. The testosterone levels with the treatment of 100,250 and $500 \mu \mathrm{g} / \mathrm{mL}$ of the various solvent extracts of the plants increased significantly. Remarkably, the testosterone levels were highest with 500 $\mu \mathrm{g} / \mathrm{mL}$ of the methanol extract of T. sambesiaca, $0.399 \mathrm{ng} /$ $\mathrm{mL}$ which were significantly greater $(P<0.05)$ than the control group $(0.038 \mathrm{ng} / \mathrm{mL})$. The acetone extracts of $P$. africanum and T. sambesiaca at $500 \mu \mathrm{g} / \mathrm{mL}$ also recorded significantly better testosterone production ( 0.147 and $0.118 \mathrm{ng} / \mathrm{mL}$, respectively) in comparison with control. Also, the methanol extract of $P$. africanum had a greater testosterone level $(0.084 \mathrm{ng} / \mathrm{mL})$ when compared with the basal control $(0.038 \mathrm{ng} / \mathrm{mL})$. In addition, the aqueous extract of T. sambesiaca at $250 \mu \mathrm{g} / \mathrm{mL}(0.105 \mathrm{ng} / \mathrm{mL})$ and $T$. emetica at $100 \mu \mathrm{g} / \mathrm{mL}(0.092 \mathrm{ng} / \mathrm{mL})$ showed a significantly high testosterone production level when compared with basal control. It is noteworthy that only the aqueous extract of X. caffra at $250 \mu \mathrm{g} / \mathrm{mL}(0.073 \mathrm{ng} / \mathrm{mL})$ was able to stimulate testosterone when compared to the control and other solvent extracts of the plant. Generally, sperm cells are defenseless against ROS; hence the enhanced or the increased testosterone product exhibited by the different plant extracts most especially by the solvent extracts of $P$. africanum and T. sambesiaca could be due to their potent radical scavenging activity. Steroid producing cells are also prone to attack by ROS and they also produce free radicals from the electron transport chain in the mitochondria by way of cytochrome P450 pathway enzymes $(88,92,93)$. Naturally, Leydig cells possess a number of antioxidant enzymes that help mop up free radicals; however, elevated levels of ROS would suppress testosterone production (93). Owing to promising antioxidant activity against free radicals, androgenic property and noncytotoxic, the selected medicinal plants could be used to boost the body's antioxidant defensive system and protect male reproduction functions from oxidative damage. Basically, 
herbal medicines are traditionally prepared using water as a solvent for remedies. Therefore, traditional healers and the African population as a whole could be encouraged to further use water as an extractant to prepare the concoction of $P$. africanum, T. emetica, T. sambesiaca, and $X$. caffra for treatment of diseases associated to elevated free radicals, infertility, and aphrodisiacs.

\section{Conclusion}

According to the results of this study, different solvent extracts of $P$. africanum, T. emetica, T. sambesiaca, and $X$. caffra showed a significant high content of flavonoids and phenolics, potent antioxidant activity. They were nontoxic on TM3 Leydig cells and enhanced testosterone production. The study suggests that the selected plant species might be used as natural antioxidants to replace the synthetic antioxidants and may be introduced in drug discovery for the development of male fertility drugs with fewer side effects. However, further study is needed to examine LC-MS analysis and high-performance liquid chromatography/photodiode array detection (HPLCPDA). Also, in vivo studies to find out the possible mechanisms of action still need to be done.

\section{Acknowledgments}

The authors would like to thank Mr. PM Dikhoba for assisting in with some of the laboratory procedures in this study. We would like to convey our gratitude to the National Research Foundation (NRF Bursary 54003/74977), Unisa Research Administration section, and National Student Aid Scheme for funding this project (Unisa Master and Doctoral Bursary: 54003/74241) and sincere thanks to University of the Western Cape researchers for providing cell lines for this study

\section{Authors' contributions}

NPM, JOU and SLL conceived and designed the study. NPM performed the experiments, NPM and JOU prepared all figures and tables in the manuscript, while NPM wrote the draft manuscript. JOU and SLL coordinated and helped to revise the manuscript. NPM, JOU and SLL read and approved the final manuscript.

\section{Conflict of interest}

The authors declare that they have no conflict of interest

\section{Ethical considerations}

The study was approved by the University of South Africa (Unisa), College of the Agriculture and Environmental Sciences Ethics Committee with protocol number 2016/ CAES/037.

\section{Funding/Support}

This study was financially supported by the National Research Foundation of South Africa and DSF-
Postgraduate of University of South Africa Research funds.

\section{References}

1. Wadood A, Ghufran M, Jamal SB, Naeem M, Khan A, Ghaffar R, et al. Phytochemical analysis of medicinal plants occurring in local area of Mardan. Biochem Anal Biochem. 2013;2(4):144. doi: 10.4172/2161-1009.1000144.

2. World Health Organization (WHO). Traditional Medicine. Geneva: WHO; 2013.

3. Moteetee A, Seleteng Kose L. Medicinal plants used in Lesotho for treatment of reproductive and post reproductive problems. J Ethnopharmacol. 2016;194:82749. doi: 10.1016/j.jep.2016.10.062.

4. Manukumar HM, Shiva Kumar J, Chandrasekhar B, Raghava S, Umesha S. Evidences for diabetes and insulin mimetic activity of medicinal plants: present status and future prospects. Crit Rev Food Sci Nutr. 2017;57(12):271229. doi: 10.1080/10408398.2016.1143446.

5. Chen L, Teng H, Jia Z, Battino M, Miron A, Yu Z, et al. Intracellular signaling pathways of inflammation modulated by dietary flavonoids: the most recent evidence. Crit Rev Food Sci Nutr. 2018;58(17):2908-24. doi: 10.1080/10408398.2017.1345853.

6. Unuofin JO, Otunola GA, Afolayan AJ. Polyphenolic content, antioxidant and antimicrobial activities of Vernonia mespilifolia Less. Used in folk medicine in the Eastern Cape Province, South Africa. J Evid Based Integr Med. 2018;23:2515690x18773990. doi: $10.1177 / 2515690 \times 18773990$.

7. Curti V, Di Lorenzo A, Dacrema M, Xiao J, Nabavi SM, Daglia M. In vitro polyphenol effects on apoptosis: an update of literature data. Semin Cancer Biol. 2017;46:11931. doi: 10.1016/j.semcancer.2017.08.005.

8. Orta Yilmaz B, Korkut A, Erkan M. Sodium fluoride disrupts testosterone biosynthesis by affecting the steroidogenic pathway in TM3 Leydig cells. Chemosphere. 2018;212:44755. doi: 10.1016/j.chemosphere.2018.08.112.

9. Sharlip ID, Jarow JP, Belker AM, Lipshultz LI, Sigman M, Thomas AJ, et al. Best practice policies for male infertility. Fertil Steril. 2002;77(5):873-82. doi: 10.1016/s00150282(02)03105-9.

10. Rojas DP, Pandey AK. Natural compounds to counteract testosterone depletion in aging. J Steroids Horm Sci. 2014;5(1):e112. doi: 10.4172/2157-7536.1000e112.

11. Chung HJ, Noh Y, Kim MS, Jang A, Lee CE, Myung SC. Steroidogenic effects of Taraxacum officinale extract on the levels of steroidogenic enzymes in mouse Leydig cells. Anim Cells Syst (Seoul). 2018;22(6):407-14. doi: 10.1080/19768354.2018.1494628.

12. Muthaura CN, Keriko JM, Mutai C, Yenesew A, Gathirwa $\mathrm{JW}$, Irungu $\mathrm{BN}$, et al. Antiplasmodial potential of traditional antimalarial phytotherapy remedies used by the Kwale community of the Kenyan Coast. J Ethnopharmacol. 2015;170:148-57. doi: 10.1016/j.jep.2015.05.024.

13. Abdillahi HS, Van Staden J. South African plants and male reproductive healthcare: conception and contraception. J Ethnopharmacol. 2012;143(2):475-80. doi: 10.1016/j. jep.2012.06.047.

14. Orwal C, Mutau A, Kindt R, Jamnadass R, Anthony S. 
Agroforestree Database: A Tree Reference and Selection Guide Version 4.0. Kenya: World Agroforestry Centre; 2009. Available from: http://www.worldagroforestry.org/af/ treedb/.

15. Samie A, Obi CL, Bessong PO, Namrita L. Activity profiles of fourteen selected medicinal plants from Rural Venda communities in South Africa against fifteen clinical bacterial species. Afr J Biotechnol. 2005;4(12):1443-51.

16. Mongalo NI. Peltophorum africanum Sond [Mosetlha]: a review of its ethnomedicinal uses, toxicology, phytochemistry and pharmacological activities. J Med Plant Res. 2013;7(48):3484-91. doi: 10.5897/jmpr2013.5302.

17. Venter F, Venter JA. Making the Most of Indigenous Trees. 2nd ed. Pretoria: Briza Publications; 2009.

18. Schemelzer GH, Gurib-Fakim A, Eds. Plant resources of tropical Africa 11 (1). Medicinal plants 1. Leiden, Netherlands: PROTA Foundation; 2008.

19. Mabogo DEN. The ethnobotany of the Vhavenda [thesis]. Pretoria, RSA: University of Pretoria; 1990.

20. De Wet H, Nzama VN, Van Vuuren SF. Medicinal plants used for the treatment of sexually transmitted infections by lay people in northern Maputaland, KwaZulu-Natal Province, South Africa. S Afr J Bot. 2012;78:12-20. doi: 10.1016/j.sajb.2011.04.002.

21. Maroyi A. Traditional use of medicinal plants in southcentral Zimbabwe: review and perspectives. J Ethnobiol Ethnomed. 2013;9:31. doi: 10.1186/1746-4269-9-31.

22. Theo A, Masebe T, Suzuki Y, Kikuchi H, Wada S, Obi CL, et al. Peltophorum africanum, a traditional South African medicinal plant, contains an anti HIV-1 constituent, betulinic acid. Tohoku J Exp Med. 2009;217(2):93-9. doi: 10.1620/tjem.217.93.

23. Semenya SS, Potgieter MJ, Erasmus LJ. Bapedi phytomedicine and their use in the treatment of sexually transmitted infections in Limpopo province, South Africa. Afr J Pharm Pharmacol. 2013;7(6):250-62. doi: 10.5897/ AJPP12.608.

24. Corrigan BM, Van Wyk BE, Geldenhuys CJ, Jardine JM. Ethnobotanical plant uses in the KwaNibela Peninsula, St Lucia, South Africa. S Afr J Bot. 2011;77(2):346-59. doi: 10.1016/j.sajb.2010.09.017.

25. Germanò MP, D’Angelo V, Biasini T, Sanogo R, De Pasquale $\mathrm{R}$, Catania S. Evaluation of the antioxidant properties and bioavailability of free and bound phenolic acids from Trichilia emetica Vahl. J Ethnopharmacol. 2006;105(3):36873. doi: 10.1016/j.jep.2005.11.029.

26. Watt JM, Breyer-Brandwijk MG. The Medicinal and Poisonous Plants of Southern and Eastern Africa. 2nd ed. Edinburgh: Livingstone; 1962.

27. de Wet H, Nkwanyana MN, van Vuuren SF. Medicinal plants used for the treatment of diarrhoea in northern Maputaland, KwaZulu-Natal Province, South Africa. J Ethnopharmacol. 2010;130(2):284-9. doi: 10.1016/j. jep.2010.05.004.

28. Würger G, McGaw LJ, Eloff JN. Tannin content of leaf extracts of 53 trees used traditionally to treat diarrhoea is an important criterion in selecting species for further work. S Afr J Bot. 2014;90:114-7. doi: 10.1016/j.sajb.2013.11.003.

29. Shai LJ, McGaw LJ, Masoko P, Eloff JN. Antifungal and antibacterial activity of seven traditionally used South
African plant species active against Candida albicans. S Afr J Bot. 2008;74(4):677-84. doi: 10.1016/j.sajb.2008.04.003.

30. Konaté K, Yomalan K, Sytar O, Brestic M. Antidiarrheal and antimicrobial profiles extracts of the leaves from Trichilia emetica Vahl. (Meliaceae). Asian Pac J Trop Biomed. 2015;5(3):242-8. doi: 10.1016/S2221-1691(15)30012-5.

31. Amusan OOG, Sukati NA, Dlamini PS, Sibandze FG. Some Swazi phytomedicines and their constituents. Afr J Biotechnol. 2007;6(3):267-72.

32. Masoko P, Eloff JN. The diversity of antifungal compounds of six South African Terminalia species (Combretaceae) determines by bioautography. Afr J Biotechnol. 2005;4(12):1425-31.

33. Chhabra SC, Mahunnah RLA, Mshiu EN. Plants used in traditional medicine in Eastern Tanzania. II. Angiosperms (capparidaceae to ebenaceae). J Ethnopharmacol. 1989;25(3):339-59. doi: 10.1016/0378-8741(89)90038-X.

34. Fyhrquist P, Mwasumbi L, Hæggström CA, Vuorela H, Hiltunen R, Vuorela P. Antifungal Activity of Selected Species of Terminalia, Pteleopsis and Combretum (Combretaceae) Collected in Tanzania. Pharm Biol. 2004;42(4-5):308-17. doi: 10.1080/13880200490511891.

35. Chauke MA, Shai LJ, Mogale MA, Tshisikhawe MP, Mokgotho MP. Medicinal plant use of villagers in the Mopani district, Limpopo Province, South Africa. Afr J Tradit Complement Altern Med. 2015;12(3):9-26. doi: 10.4314/ajtcam.v12i3.2.

36. Bruschi P, Morganti M, Mancini M, Signorini MA. Traditional healers and laypeople: a qualitative and quantitative approach to local knowledge on medicinal plants in Muda (Mozambique). J Ethnopharmacol. 2011;138(2):543-63. doi: 10.1016/j.jep.2011.09.055.

37. Ndhlovu DN, Masika PJ. Ethno-veterinary control of bovine dermatophilosis and ticks in Zhombe, Njelele and Shamrock resettlement in Zimbabwe. Trop Anim Health Prod. 2013;45(2):525-32. doi: 10.1007/s11250-012-0253-7.

38. Mulaudzi RB, Ndhlala AR, Kulkarni MG, Finnie JF, Van Staden J. Antimicrobial properties and phenolic contents of medicinal plants used by the Venda people for conditions related to venereal diseases. J Ethnopharmacol. 2011;135(2):330-7. doi: 10.1016/j.jep.2011.03.022.

39. Nair JJ, Mulaudzi RB, Chukwujekwu JC, Van Heerden FR, Van Staden J. Antigonococcal activity of Ximenia caffra Sond. (Olacaceae) and identification of the active principle. S Afr J Bot. 2013;86:111-5. doi: 10.1016/j.sajb.2013.02.170.

40. Masoko P, Mmushi TJ, Mogashoa MM, Mokgotho MP, Mampuru LJ, Howard RL. In vitro evaluation of the antifungal activity of Sclerocarya birrea extracts against pathogenic yeasts. Afr J Biotechnol. 2008;7(20):3521-26.

41. Makkar HPS. Quantification of tannin in tree foliage. A laboratory Manual for the FAQ/IAEA Co-ordinated Research Project on Use for Nuclear and Related Techniques to Develop Simple Tannin Assay for Predicting and Improving the Safety and Efficiency of Feeding Ruminants on the Tanniferous Tree Foliage. Vienna, Austria: Joint FAQ/IAEA on Nuclear Techniques in Food and Agriculture; 1999.

42. Adebayo SA, Dzoyem JP, Shai LJ, Eloff JN. The antiinflammatory and antioxidant activity of 25 plant species used traditionally to treat pain in southern African. BMC 
Complement Altern Med. 2015;15:159. doi: 10.1186/ s12906-015-0669-5.

43. Parthasarathy S, Bin Azizi J, Ramanathan S, Ismail S, Sasidharan S, Said MI, et al. Evaluation of antioxidant and antibacterial activities of aqueous, methanolic and alkaloid extracts from Mitragyna speciosa (Rubiaceae family) leaves. Molecules. 2009;14(10):3964-74. doi: 10.3390/ molecules14103964.

44. Yadav RNS, Agarwal M. Phytochemical analysis of some medicinal plants. J Phytol. 2011;3(12):10-4.

45. Miliauskas G, Venskutonis PR, van Beek TA. Screening of radical scavenging activity of some medicinal and aromatic plant extracts. Food Chem. 2004;85(2):231-7. doi: 10.1016/j. foodchem.2003.05.007.

46. Mensor LL, Menezes FS, Leitão GG, Reis AS, dos Santos TC, Coube CS, et al. Screening of Brazilian plant extracts for antioxidant activity by the use of DPPH free radical method. Phytother Res. 2001;15(2):127-30. doi: 10.1002/ ptr.687.

47. Hamzah RU, Jigam AA, Makun HA, Egwin EC. Phytochemical screening and invitro antioxidant activity of methanolic extract of selected Nigerian vegetables. Asian J Basic Appl Sci. 2014;1(1):1-14.

48. Monsees TK, Franz M, Gebhardt S, Winterstein U, Schill WB, Hayatpour J. Sertoli cells as a target for reproductive hazards. Andrologia. 2000;32(4-5):239-46. doi: 10.1046/j.1439-0272.2000.00391.x.

49. Mahapatra A, Mativandlela SP, Binneman B, Fourie PB, Hamilton CJ, Meyer JJ, et al. Activity of 7-methyljuglone derivatives against Mycobacterium tuberculosis and as subversive substrates for mycothiol disulfide reductase. Bioorg Med Chem. 2007;15(24):7638-46. doi: 10.1016/j. bmc.2007.08.064.

50. Mosmann T. Rapid colorimetric assay for cellular growth and survival: application to proliferation and cytotoxicity assays. J Immunol Methods. 1983;65(1-2):55-63. doi: 10.1016/0022-1759(83)90303-4.

51. Fadipe VO, Mongalo NI, Opoku AR. In vitro evaluation of the comprehensive antimicrobial and antioxidant properties of Curtisia dentata (Burm.f) C.A. Sm: toxicological effect on the Human embryonic kidney (HEK293) and Human hepatocellular carcinoma (HepG2) cell lines. EXCLI J. 2015;14:971-83. doi: 10.17179/excli2015-351.

52. Złotek U, Mikulska S, Nagajek M, Świeca M. The effect of different solvents and number of extraction steps on the polyphenol content and antioxidant capacity of basil leaves (Ocimum basilicum L.) extracts. Saudi J Biol Sci. 2016;23(5):628-33. doi: 10.1016/j.sjbs.2015.08.002.

53. Nemudzivhadi V, Masoko P. Antioxidant and antibacterial properties of Ziziphus mucronata and Ricinus communis leaves extracts. Afr J Trad Complement Altern Med. 2015;12(1):81-9. doi: 10.4314/ajtcam.v12i1.12.

54. Masoko P, Picard J, Eloff JN. Antifungal activities of six South African Terminalia species (Combretaceae). J Ethnopharmacol. 2005;99(2):301-8. doi: 10.1016/j. jep.2005.01.061.

55. Klimczak I, Małecka M, Szlachta M, GliszczyńskaSwigło A. Effect of storage on the content of polyphenols, vitamin $\mathrm{C}$ and the antioxidant activity of orange juices. J Food Compost Anal. 2007;20(3-4):313-22. doi: 10.1016/j. jfca.2006.02.012.

56. Tahara S. A journey of twenty-five years through the ecological biochemistry of flavonoids. Biosci Biotechnol Biochem. 2007;71(6):1387-404. doi: 10.1271/bbb.70028.

57. Giorgi A, Mingozzi M, Madeo M, Speranza G, Cocucci M. Effect of nitrogen starvation on the phenolic metabolism and antioxidant properties of yarrow (Achillea collina Becker ex Rchb.). Food Chem. 2009;114(1):204-11. doi: 10.1016/j.foodchem.2008.09.039.

58. Masuku NP, Lebelo SL. Investigation of the effects of Kigelia africana (Lam.) Benth. Extracts on TM3 Leydig cells. Asian J Pharm Clin Res. 2019;12(10):87-92.

59. Sharifi-Rad J, Hoseini-Alfatemi SM, Miri A, Sharifi-Rad M, Soufi L, Sharifi-Rad M, et al. Phytochemical analysis, antioxidant and antibacterial activities of various extracts from leaves and stems of Chrozaphora tinctoria. Environ Exp Biol. 2015;13:169-75.

60. Daoud A, Malika D, Bakari S, Hfaiedh N, Mnafgui K, Kadri A, et al. Assessment of polyphenol composition, antioxidant and antimicrobial properties of various extracts of Date Palm Pollen (DPP) from two Tunisian cultivars. Arab J Chem. 2019;12(8):3075-86. doi: 10.1016/j. arabjc.2015.07.014.

61. Unuofin JO, Otunola GA, Afolayan AJ. In vitro alphaamylase, alpha-glucosidase, lipase inhibitory and cytotoxic activities of tuber extracts of Kedrostis africana (L.) Cogn. Heliyon. 2018;4(9):e00810. doi: 10.1016/j.heliyon.2018. e00810.

62. El-Chaghaby GA, Ahmad AF, Ramis ES. Evaluation of the antioxidant and antibacterial properties of various solvents extracts of Annona squamosa L. leaves. Arab J Chem. 2014;7(2):227-33. doi: 10.1016/j.arabjc.2011.06.019.

63. Farasat M, Khavari-Nejad RA, Nabavi SM, Namjooyan F. Antioxidant activity, total phenolics and flavonoid contents of some edible green seaweeds from northern coasts of the Persian Gulf. Iran J Pharm Res. 2014;13(1):163-70.

64. Unuofin JO, Otunola GA, Afolayan AJ. Phytochemical screening and in vitro evaluation of antioxidant and antimicrobial activities of Kedrostis africana (L.) Cogn. Asian Pac J Trop Biomed. 2017;7(10):901-8. doi: 10.1016/j. apjtb.2017.09.008.

65. Koolen HHF, da Silva FMA, Gozzo FC, de Souza AQL, de Souza ADL. Antioxidant, antimicrobial activities and characterization of phenolic compounds from buriti (Mauritia flexuosa L. f.) by UPLC-ESI-MS/MS. Food Res Int. 2013;51(2):467-73. doi: 10.1016/j.foodres.2013.01.039.

66. Bakhtiar SI, Shahriar M, Akhter R, Bhuiyan MA. In vitro antioxidant activities of the whole plant extract of Chrozophora prostrata (dalz.). Ann Biol Res. 2015;6(4):1926.

67. Beseni BK, Bagla VP, Njanje I, Matsebatlela TM, Mampuru L, Mokgotho MP. Antioxidant, antiglycation, and hypoglycaemic effect of Seriphium plumosum crude plant extracts. Evid Based Complement Alternat Med. 2017;2017:6453567. doi: 10.1155/2017/6453567.

68. Ak T, Gülçin I. Antioxidant and radical scavenging properties of curcumin. Chem Biol Interact. 2008;174(1):2737. doi: 10.1016/j.cbi.2008.05.003.

69. Floegel A, Kim D-O, Chung SJ, Koo SI, Chun OK. Comparison of ABTS/DPPH assays to measure antioxidant 
capacity in popular antioxidant-rich US foods. J Food Compost Anal. 2011;24(7):1043-8. doi: 10.1016/j. jfca.2011.01.008.

70. Krishnaiah D, Sarbatly R, Nithyanandam R. A review of the antioxidant potential of medicinal plant species. Food Bioprod Process. 2011;89(3):217-33. doi: 10.1016/j. fbp.2010.04.008.

71. Do QD, Angkawijaya AE, Tran-Nguyen PL, Huynh LH, Soetaredjo FE, Ismadji S, et al. Effect of extraction solvent on total phenol content, total flavonoid content, and antioxidant activity of Limnophila aromatica. J Food Drug Anal. 2014;22(3):296-302. doi: 10.1016/j.jfda.2013.11.001.

72. Bizimenyera ES, Aderogba MA, Eloff JN, Swan GE. Potential of neuroprotective antioxidant-based therapeutics from Peltophorum africanum Sond. (Fabaceae). Afr J Tradit Complement Altern Med. 2006;4(1):99-106. doi: 10.4314/ ajtcam.v4i1.31199.

73. Komane BM, Olivier EI, Viljoen AM. Trichilia emetica (Meliaceae) - a review of traditional uses, biological activities and phytochemistry. Phytochem Lett. 2011;4(1):19. doi: 10.1016/j.phytol.2010.11.002.

74. Tshikalange TE, Mamba P, Adebayo SA. Antimicrobial, antioxidant and cytotoxicity studies of medicinal plants used in the treatment of sexually transmitted diseases. Int J Pharmacogn Phytochem Res. 2016;8(11):1891-95.

75. Masoko P, Eloff JN. Screening of twenty-four South African Combretum and six Terminalia species (Combretaceae) for antioxidant activities. Afr J Tradit Complement Altern Med. 2006;4(2):231-9. doi: 10.4314/ajtcam.v4i2.31213.

76. Mokgoatsane SI. The isolation and characterization of antibacterial compound from Terminalia sambesiaca (Combretaceae) [dissertation]. North-West University; 2011. p. 192.

77. Yao X, Shang E, Zhou G, Tang Y, Guo S, Su S, et al. Comparative characterization of total flavonol glycosides and terpene lactones at different ages, from different cultivation sources and genders of Ginkgo biloba leaves. Int J Mol Sci. 2012;13(8):10305-15. doi: 10.3390/ijms130810305.

78. Pandey A, Tripathi S. Concept of standardization, extraction and pre phytochemical screening strategies for herbal drug. J Pharmacogn Phytochem. 2014;2(5):115-9.

79. Bessong PO, Obi CL, Andréola ML, Rojas LB, Pouységu L, Igumbor E, et al. Evaluation of selected South African medicinal plants for inhibitory properties against human immunodeficiency virus type 1 reverse transcriptase and integrase. J Ethnopharmacol. 2005;99(1):83-91. doi: 10.1016/j.jep.2005.01.056.

80. Mazimba O. Pharmacology and phytochemistry studies in Peltophorum africanum. Bull Fac Pharm Cairo Univ. 2014;52(1):145-53. doi: 10.1016/j.bfopcu.2014.01.001.

81. Okeleye BI, Nongogo V, Mkwetshana NT, Ndip RN. Polyphenolic content and in vitro antioxidant evaluation of the stem bark extract of Peltophorum africanum sond (fabaceae). Afr J Tradit Complement Altern Med. 2015;12(1):1-8.

82. Traore M, Zhai L, Chen M, Olsen CE, Odile N, Pierre GI, et al. Cytotoxic kurubasch aldehyde from Trichilia emetica. Nat Prod Res. 2007;21(1):13-7. doi: 10.1080/14786410600921698.

83. Zhen J, Guo Y, Villani T, Carr S, Brendler T, Mumbengegwi $\mathrm{DR}$, et al. Phytochemical analysis and anti-inflammatory activity of the extracts of the African medicinal plant Ximenia caffra. J Anal Methods Chem. 2015;2015:948262. doi: 10.1155/2015/948262.

84. Galano A, Mazzone G, Alvarez-Diduk R, Marino T, Alvarez-Idaboy JR, Russo N. Food antioxidants: chemical insights at the molecular level. Annu Rev Food Sci Technol. 2016;7:335-52. doi: 10.1146/annurev-food-041715-033206.

85. Nimse SB, Pal D. Free radicals, natural antioxidants, and their reaction mechanisms. RSC Adv. 2015;5(35):2798628006. doi: 10.1039/C4RA13315C.

86. Fotakis G, Timbrell JA. In vitro cytotoxicity assays: comparison of $\mathrm{LDH}$, neutral red, MTT and protein assay in hepatoma cell lines following exposure to cadmium chloride. Toxicol Lett. 2006;160(2):171-7. doi: 10.1016/j. toxlet.2005.07.001.

87. Walker WH. Testosterone signaling and the regulation of spermatogenesis. Spermatogenesis. 2011;1(2):116-20. doi: 10.4161/spmg.1.2.16956.

88. Opuwari CS, Monsees TK. Reduced testosterone production in TM3 Leydig cells treated with Aspalathus linearis (Rooibos) or Camellia sinensis (tea). Andrologia. 2015;47(1):52-8. doi: 10.1111/and.12221.

89. Petersen PM, Seieroe K, Pakkenberg B. The total number of Leydig and Sertoli cells in the testes of men across various age groups - a stereological study. J Anat. 2015;226(2):1759. doi: 10.1111/joa.12261.

90. Abdel-Hameed ES, Bazaid SA, Shohayeb MM, El-Sayed MM, El-Wakil EA. Phytochemical studies and evaluation of antioxidant, anticancer and antimicrobial properties of Conocarpus erectus L. growing in Taif, Saudi Arabia. European J Med Plants. 2012;2(2):93-112. doi: 10.5281/ zenodo.8671.

91. Liu PY, Baker HW, Jayadev V, Zacharin M, Conway AJ, Handelsman DJ. Induction of spermatogenesis and fertility during gonadotropin treatment of gonadotropin-deficient infertile men: predictors of fertility outcome. J Clin Endocrinol Metab. 2009;94(3):801-8. doi: 10.1210/jc.20081648.

92. Zangar RC, Davydov DR, Verma S. Mechanisms that regulate production of reactive oxygen species by cytochrome P450. Toxicol Appl Pharmacol. 2004;199(3):316-31. doi: 10.1016/j.taap.2004.01.018.

93. Aitken RJ, Roman SD. Antioxidant systems and oxidative stress in the testes. Oxid Med Cell Longev. 2008;1(1):15-24. doi: 10.4161/oxim.1.1.6843. 